\title{
Comparative Analysis of Six Phase Induction Motor
}

\author{
İsmail Sarıgül ${ }^{*} \mathbb{( \mathbb { C }}$, Mehmet Özdemir ${ }^{2}(\mathbb{D}$ \\ ${ }^{1 *}$ Inonu University, Electrical and Electronics Engineering Department,Malatya, Turkey. (e-mail:ismail.sarigul@inonu.edu.tr). \\ ${ }^{2}$ Firat University, Electrical and Electronics Engineering Department, Elazığ, Turkey. (e-mail:mozdemır@ firat.edu.tr).
}

\section{ARTICLE INFO}

Received: Oct., 15. 2020

Revised: May, 21. 2021

Accepted: Aug., 10. 2021

Keywords:

Induction motor

Six phase

d-q model

Simulation

Three phase

Corresponding author: Ismail Sarigül

ISSN: 2536-5010 | e-ISSN: 2536-5134

DOI: https://doi.org/10.36222/ejt.811334

\section{ABSTRACT}

In recent years, AC induction motors have replaced DC motor. The most important reason for this is that DC motors have a mechanical brush and commutator system that is subject to wear and tear over time. While DC motor drivers need a lot of maintenance due to this system, induction motors do not require almost any maintenance since this system is not available. In recent years, technological advances in the field of multiphase induction motors have led to a significant evolution. A lot of research has been done around the world and a lot of new and interesting developments have been reported to the literature.

This paper provides information about six-phase induction. In addition, what kind of advantages the concept of multiphase provides and how this structure is formed contains information about them. The six-phase induction motor will be simulated through the MATLAB/SIMULINK package program and compare with three-phase induction motor. Both motors were run in simulation using the same parameters. At the end of the simulation, current, moment and speed graphs of the six-phase induction motor and three-phase induction motor will be drawn according to time. The study also included equations used during modeling and equivalent circuits belonging to a six-phase induction motor. It has been graphically shown that a six-phase induction motor is more advantageous than a threephase motor. For example, in six-phase induction motors, the transition time to a continuous state is shorter. In addition, while the frequency of torque vibration increases, its amplitude decreases, the current value of each phase decreases, the stator copper losses are less than the three-phase induction motor. In motors, usually the power needed is divided by the number of phases. So the more phases there are, the greater the power carrying capacity. Today, multi-phase induction motor drives are used in special applications such as electric vehicles, space technology, aerospace applications, as moving power on ships, electric trains, which require high reliability and power.

\section{INTRODUCTION}

Due to the benefits they offer, induction motors have becomea form of motor that is commonlyused in today's industy The absence of mechanical brushes and collectors is one o these benefits. As is known, DC motors include in their structures a brush and collector device. Over time, this system is prone to wear and tear. DC motors need more frequent maintenance requirements for this reason. In comparison, induction motors require almost no maintenance.

Thanks to unnecessary maintenance standards, DC motors have been replaced by induction motors. In recent years, research on induction motors has increased around the world, and an attempt has been made to look for answers to the question of how induction motors can be used even more efficiently.In induction motors, which are divided into two types according to rotor structures, squirrel cage induction motors are a type of motor that we often encounter in factories due to their cheap and robust structure. Slip ring induction motors, which are more expensive than squirrel cage induction motors, are preferred in applications requiring high starting torque.

The voltage levels of today's induction motors differ from a few watts to high power levels such as $35 \mathrm{MW}$, from 110 $\mathrm{V}$ to $27 \mathrm{kV}$ [1].

Induction motors, which are also produced in singlephase in small power systems, are usually produced in three-phase. In the current situation, induction motors are more commonly used in a three-phase structure, so they are known in the literature as traditional three-phase induction motors. Apart from three phase and single phase induction motors, the concept of multi-phase induction motor has taken its place in the literature in recent years. The concept of multiphase induction motor is a general name given to induction motors with more than three phases. The first official records are known by the authors as dating back to 1969 , and for the first time it is suggested that multiphase 
motor drives are induction motors feed five-phase voltage source inverter [2]. Generally, compared to traditional three-phaseinducion machines, multi phase induciton machines have many advantages.

Some of these advantages are as follows;

- As the number of phases increases, the required power is divided among multiple phases, thus providing higher power carrying capacity,

- Vibration of the torque decreases

- Better as reliability

- The start or operation of the induction machine is not prevented by phase loss in the stator,

- In comparison to a threephase machine of the same scale, the moment produced per ampere

increases.

- Copper losses occurring in the stator are reduced,

- The rotor's harmonic current decreases according to the angle of placement [3].

Ships, electric or hybrid cars, aircraft, electric trains, spacecraft and systems requiring high power are the major areas of operation for multi-phase induction motors [4].

\section{MODELLING OF THREE PHASE AND SIX PHASE INDUCTION MOTOR}

Induction motors basically have two main components; the stator, which is stationary, and the rotor, which makes a rotational movement [5]. From these components, the task of the stator is to create a magnetic field, while the task of the rotor is to produce the force that provides movement.

It was mentioned that the concept of multiphase is used for motors whose stator has more than three phase numbers. Here, six-phase induction motor will be examined as a multi-phase induction motor. Six-phase induction motors have a double three-phase winding structure. First, one three-phase winding group is placed in the stator, and the other three phase winding groups are placed in such a way that there is a $30^{\circ}$ electrical phase difference between the first winding group. This structure (dual 3-phase) enables better torque generation compared to traditional three-phase motors. This function makes them ideal for applications.For example, ship propulsion, spacecraft and electric vehicles requiring high current and high power [6].

Initially, it was thought that the spatial displacement between two stator phases in sequence in an m-phase symmetric induction machine was determined by the formula $\alpha=2 \pi / \mathrm{m}$. The stator windings were treated as $\mathrm{m}$-phases and the windings were assumed to be sinusoidal distributed, so the higher harmonics of the magne-motor force in the whole space were negligible. The number of phases $(\mathrm{m})$ can be single or double.

The problem of magnetic circulating currents arose when dual three-phase windings were designed with a $60^{\circ}$ displacement angle according to the formula. Therefore, the double three-phase windings were placed asymmetrically at an angle of $30^{\circ}$ so that some harmonics $(6 n+1)$ were eliminated. $(\mathrm{n}=1,3,5 \ldots)$ [7].

\subsection{Multi-Phase Induction Motor Model}

In this study, d-q transformations are used when constructing the simulink model of a six-phase induction motor.

Some assumptions are made as follows, in order to constr uct the model.

- The air gap between the stator and the rotor is identical, the windings of stator are distributed evenly throughout the air gap.

- Friction and wind losses are neglected in the system.

- There has been neglect of magnetic saturation and core losses [8].

Parameters of motors shows Table I.

TABLE I

PARAMETERS OF MOTORS

\begin{tabular}{ll}
\hline \hline & Value \\
\hline Parameters & 1.9 \\
\hline $\mathrm{r}_{\mathrm{s}}(\Omega)$ & 2.1 \\
$\mathrm{r}_{\mathrm{r}}(\Omega)$ & 0.0132 \\
$\mathrm{~L}_{\mathrm{ls}}(\mathrm{H})$ & 0.0132 \\
$\mathrm{~L}_{\mathrm{lr}}(\mathrm{H})$ & 1 \\
$\mathrm{~L}_{\mathrm{m}}(\mathrm{H})$ & 0.011 \\
$\mathrm{~L}_{\mathrm{lm}}(\mathrm{H})$ & 230 \\
$\mathrm{~V}_{\mathrm{n}}(\mathrm{volt})$ & 50 \\
$\mathrm{f}(\mathrm{Hz})$ & 2 \\
$\mathrm{P}$ & 3 \\
Rated Power(KW) & 299.46 \\
Nominal speed $(\mathrm{rad} / \mathrm{sn})$ & \\
& \\
\hline \hline
\end{tabular}

The simplified six-phase induction motor diagram is shown in Figure. 1

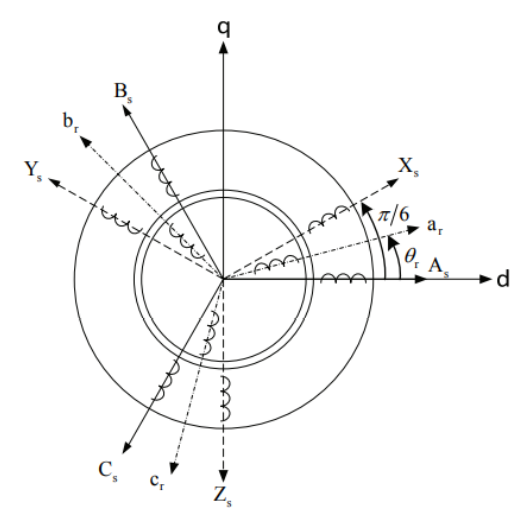

Figure 1. Simplified six-phase induction motor model

The voltage equations of six-phase induction motor are given below[9];

$$
\begin{array}{r}
V_{q s 1}=r_{s} \cdot i_{q s 1}+\frac{d}{d t} \varphi_{q s 1}+\omega \cdot \varphi_{d s 1} \\
V_{d s 1}=r_{s} \cdot i_{d s 1}+\frac{d}{d t} \varphi_{d s 1}-\omega \cdot \varphi_{q s 1} \\
V_{q s 2}=r_{s} \cdot i_{q s 2}+\frac{d}{d t} \varphi_{q s 2}+\omega \cdot \varphi_{d s 2} \\
V_{d s 2}=r_{s} \cdot i_{d s 2}+\frac{d}{d t} \varphi_{d s 2}-\omega \cdot \varphi_{q s 2} \\
V_{q r}^{\prime}=r_{r}^{\prime} \cdot i_{q r}^{\prime}+\frac{d}{d t} \varphi_{q r}^{\prime}+\left(\omega-\omega_{r}\right) \cdot \varphi_{d r}^{\prime}
\end{array}
$$




$$
=r_{r}^{\prime} \cdot i_{d r}^{\prime}+\frac{d}{d t} \varphi_{d r}^{\prime}-\left(\omega-\omega_{r}\right) \cdot \varphi_{q r}^{\prime}
$$

The flux relation equations are;

$$
\begin{array}{r}
\varphi_{q s 1}=L_{l s} \cdot i_{q s 1}+L_{l m}\left(i_{q s 1}+i_{q s 2}\right)+L_{m} \cdot\left(i_{q s 1}+i_{q s 2}+i_{q r}^{\prime}\right) \\
\varphi_{d s 1}=L_{l s} \cdot i_{d s 1}+L_{l m}\left(i_{d s 1}+i_{d s 2}\right)+L_{m} \cdot\left(i_{d s 1}+i_{d s 2}+i_{d r}^{\prime}\right) \\
\varphi_{q s 2}=L_{l s} \cdot i_{q s 2}+L_{l m}\left(i_{q s 1}+i_{q s 2}\right)+L_{m} \cdot\left(i_{q s 1}+i_{q s 2}+i_{q r}^{\prime}\right) \\
\varphi_{d s 2}=L_{l s} \cdot i_{d s 2}+L_{l m}\left(i_{d s 1}+i_{d s 2}\right)+L_{m} \cdot\left(i_{d s 1}+i_{d s 2}+i_{d r}^{\prime}\right) \\
\varphi^{\prime}{ }_{q r}=L_{l r}^{\prime} \cdot i^{\prime}{ }_{q r}+L_{m} \cdot\left(i_{q s 1}+i_{q s 2}+i^{\prime}{ }_{q r}\right) \\
\varphi_{d r}^{\prime}=L^{\prime}{ }_{l r} \cdot i^{\prime}{ }_{d r}+L_{m} \cdot\left(i_{d s 1}+i_{d s 2}+i^{\prime}{ }_{d r}\right)
\end{array}
$$

The electromagnetic torque $(\mathrm{Te})$ can be calculated from the equation below[9];

$T e=\left(\frac{3}{2}\right)\left(\frac{P}{2}\right)\left(\frac{L_{m}}{L_{r}^{\prime}}\right)\left[\varphi_{d r^{\prime}}^{\prime}\left(i_{q s 1}+i_{q s 2}\right)-\varphi_{q r^{\cdot}}^{\prime}\left(i_{d s 1}+i_{d s 2}\right)\right]$

The rotor speed equation is;

$$
\omega_{r}=\left(\frac{1}{J_{r}}\right) \cdot \int\left(T_{e}-T_{l}\right) d t
$$

The six-phase induction motor model d-q was created on the reference frame. Figure.2 shows the d-axis single phase equivalent circuit and the Figure. 3 shows q-axis singlephase equivalent.

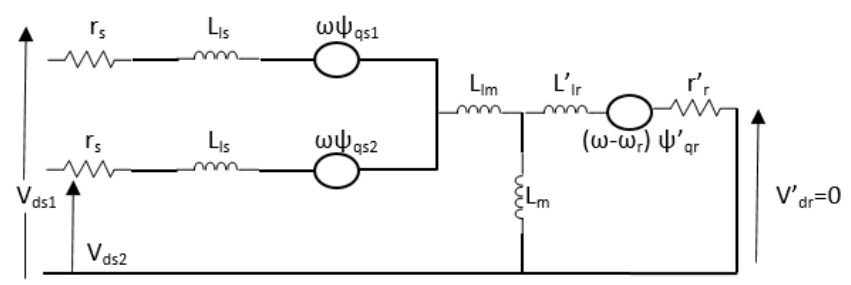

Figure 2. Single phase equivalent circuit of a dynamic d-axis six-phase induction motor

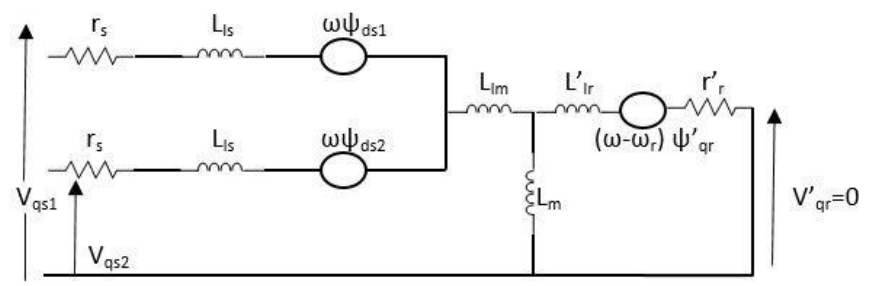

Figure 3. Single phase equivalent circuit of a dynamic q-axis six-phase induction motor

\subsection{Three-Phase Induction Motor Model}

In this study, d-q transformations are used when constructing the simulink model of a three-phase induction motor. The assumptions stated in the six-phase induction motor model also apply to the three-phase induction motor.

The voltage equation of the motor are mentioned below[9];

$$
\begin{array}{r}
V_{q s}=r_{s} \cdot i_{q s}+\frac{d}{d t} \varphi_{q s}+\omega \cdot \varphi_{d s} \\
V_{d s}=r_{s} \cdot i_{d s}+\frac{d}{d t} \varphi_{d s}-\omega \cdot \varphi_{q s} \\
V_{q r}^{\prime}=r_{r}{ }_{r} . i^{\prime}{ }_{q r}+\frac{d}{d t} \varphi^{\prime}{ }_{q r}+\left(\omega-\omega_{r}\right) \cdot \varphi^{\prime}{ }_{d r}
\end{array}
$$

$$
V_{d r}^{\prime}=r_{r}^{\prime} . i_{d r}^{\prime}+\frac{d}{d t} \varphi_{d r}^{\prime}-\left(\omega-\omega_{r}\right) \cdot \varphi_{q r}^{\prime}
$$

The flux linkage equations are as follows;

$$
\begin{array}{r}
\varphi_{q s}=L_{l s} \cdot i_{q s}+L_{m}\left(i_{q s}+i_{q r}^{\prime}\right) \\
\varphi_{d s}=L_{l s} \cdot i_{d s}+L_{m} \cdot\left(i_{d s}+i_{d r}^{\prime}\right) \\
\varphi_{q r}^{\prime}=L_{l r}^{\prime} \cdot i_{q r}^{\prime}+L_{m} \cdot\left(i_{q s}+i^{\prime}{ }_{q r}\right) \\
\varphi_{d r}^{\prime}=L_{l r}^{\prime} \cdot i_{d r}^{\prime}+L_{m} \cdot\left(i_{d s}+i_{d r}^{\prime}\right)
\end{array}
$$

The electromagnetic torque (Te) can be calculated from the equation below:

$$
T e=\left(\frac{3}{2}\right) \cdot\left(\frac{P}{2}\right) \cdot\left(\frac{L_{m}}{L_{r}^{\prime}}\right) \cdot\left[\varphi_{d r^{\prime}}^{\prime}\left(i_{q s}\right)-\varphi^{\prime}{ }_{r^{\prime}} \cdot\left(i_{d s}\right)\right]
$$

The rotor speed equation is

$$
\omega_{r}=\left(\frac{1}{J_{r}}\right) \cdot \int\left(T_{e}-T_{l}\right) d t
$$

\section{SIMULATION RESULTS}

In this part of the study, the six-phase induction motor model was fed by six single-phase sources. The motor is loaded for certain periods of time and its results are graphically shown. Simulink model of six-phase induction motor is shown in Figure.4. After the first run, a three-phase induction motor with three-phase same parameters was started. Simulink model and graphics of three phase induction motor are also presented.

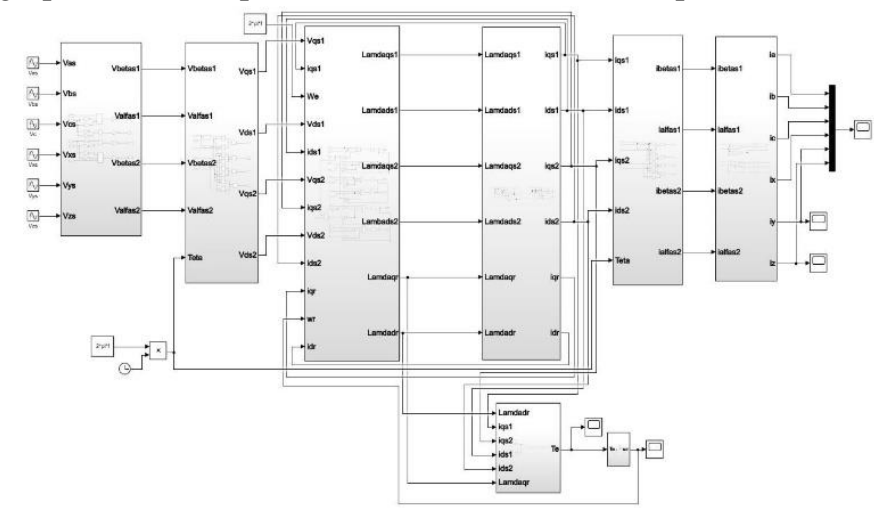

Figure 4. Simulink model of six-phase induction motor

The induction motor was operated without load for $0-2$ seconds, with load moment of 5 N.m between 2-4 seconds and with load moment of 10 N.m between 4-6 seconds. Figure-5 shows six phase current graphs taken at the output of a sixphase induction motor. 


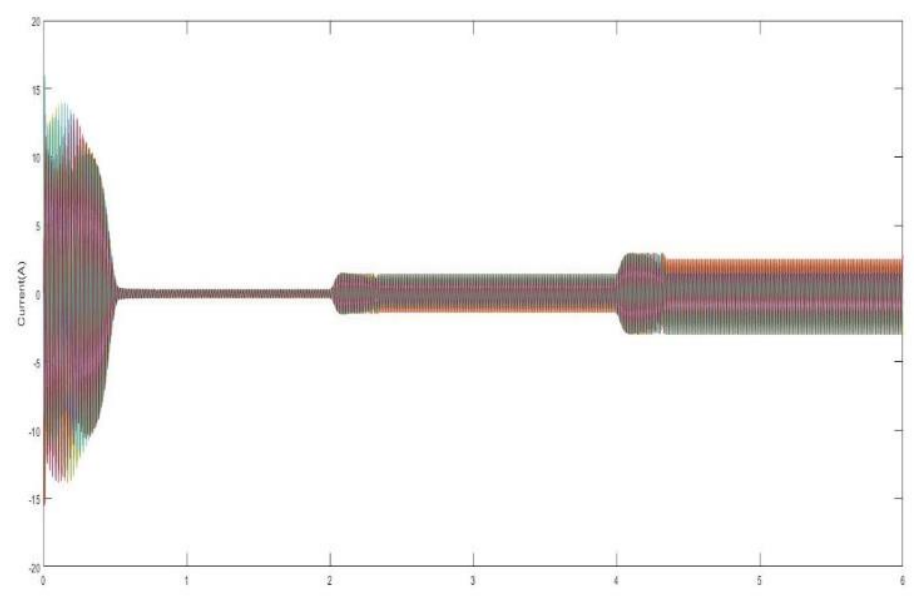

Figure 5. Currents of six-phase induction motor

Figure-6 shows speed response and Figure-7 shows electromagnetic torque response of six phase induction motor.

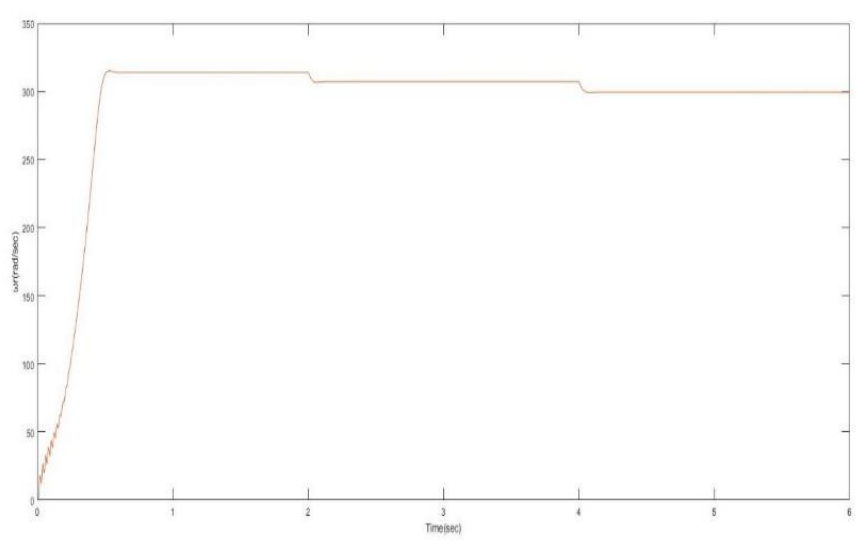

Figure 6. Speed response of six-phase induction motor

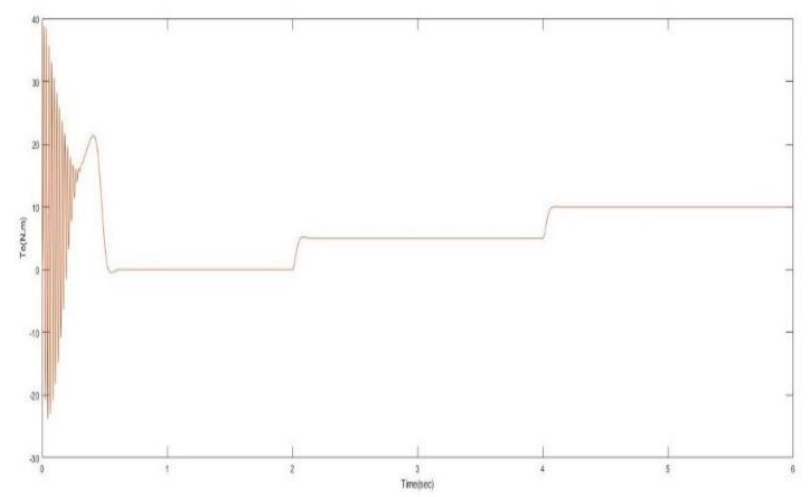

Figure 7. Electromagnetic torque response of six phase induction motor

Similarly, a three-phase induction motor with the same parameters was started and the following results were obtained. Simulink model of three-phase induction motor is shown in Figure.8.

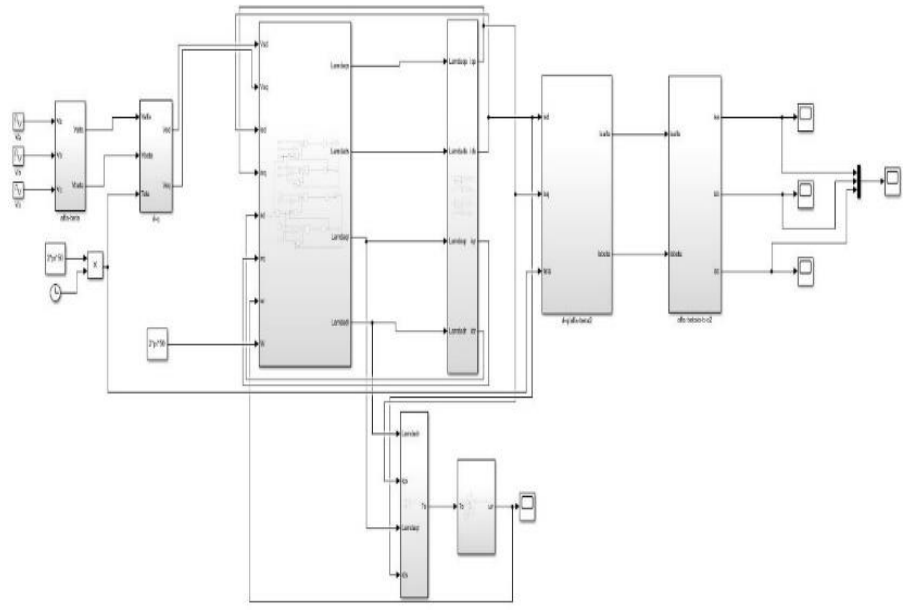

Figure 8. Simulink model of three-phase induction motor

Figure-9 shows three phase current graphs taken at the output of a three-phase induction motor.

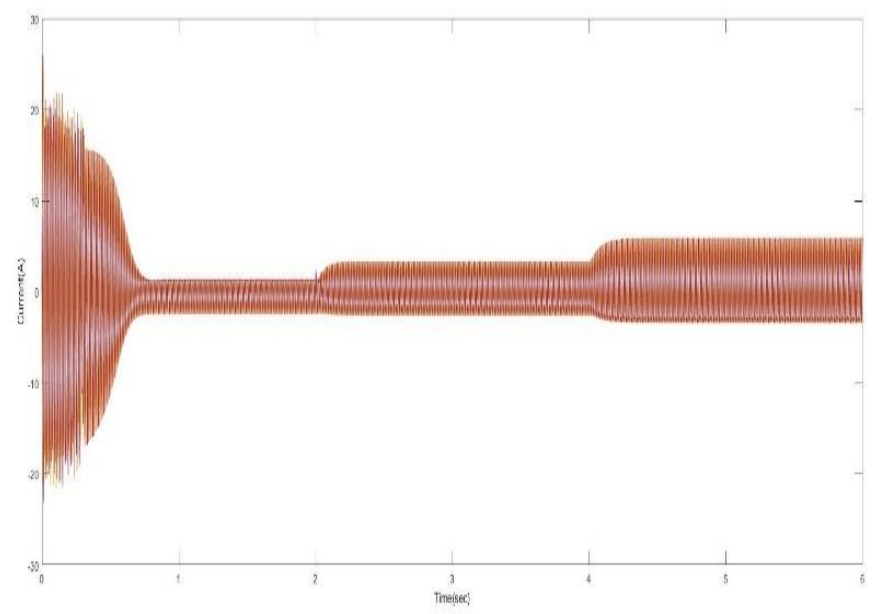

Figure 9. Currents of three-phase induction motor

Figure-10 shows speed response and Figure-11 shows electromagnetic torque response of three phase induction motor.

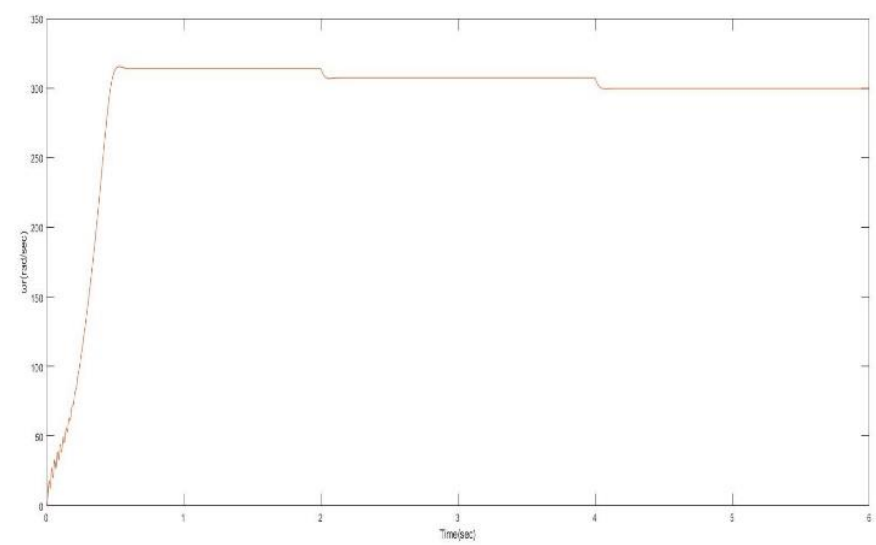

Figure 10. Speed response of three-phase induction motor 


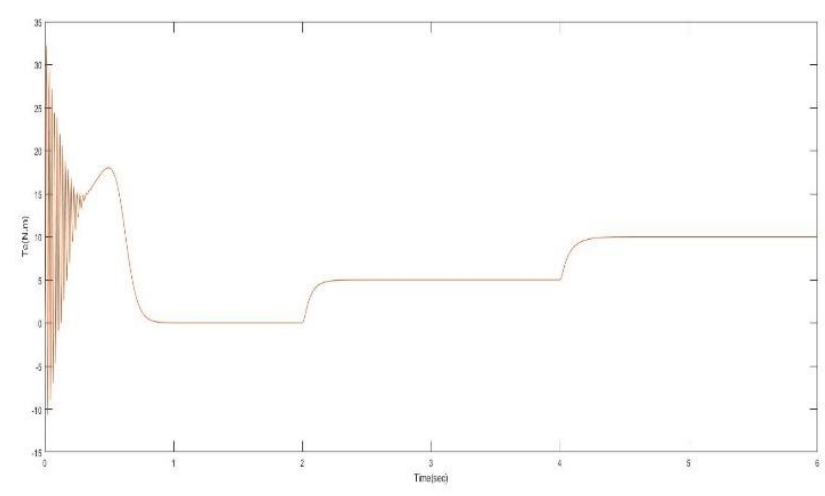

Figure 11. Electromagnetic torque response of three-phase induction motor

Some values for the results are given in Table II.

TABLE II

COMPARISON OF PERFORMANCE OF SPIM AND TPIM UNDER SAME CONDITIONS

\begin{tabular}{lll}
\hline \hline Parameters & SPIM & TPIM \\
\hline No-load current (A) & 0.605 & 1.441 \\
5-Nm load current(A) & 1.515 & 3.468 \\
10-Nm(nominal) load current(A) & 3.03 & 6.375 \\
Settling time (sec) & 0.552 & 0.882 \\
Stator copper loss for nominal-load (W) & 104.66 & 231.65 \\
& & \\
\hline \hline
\end{tabular}

\section{CONCLUSION}

As induction motors are commonly used, it is noted that st udies of induction motor control are also widely used. The multi (six) phase induction motor structure, which is more advantageous than the traditional three-phase induction motor, has become a subject that is widely used in other countries and many studies have been made. With the development of power electronics, inverters have become more useful and this has facilitated the control of multi-phase induction motors.

In this study, the multi-phase induction motor model was operated using six single-phase sources in MATLAB/Simulink. Then the three-phase induction motor is modeled in the same package program. The same parameters are used for both induction motors during the simulation. In the literature, the same parameters were used for both motor in comparison studies. But even if they have the same parameters, it seems to be more advantageous because there are two groups of three-phase windings in a six-phase induction motor.

According to the simulation results, six-phase induction motor is more advantageous than the traditional three-phase induction motor.

From the result, the advantages of six phase induction motor over conventional three phase induction motor, which are given below, have been shown to deliver better performance;

- When the speed-time graph is examined, it has been observed that the speed decreases very slightly in loading situations,

- According to the moment-time graph, the six-phase induction motor has a higher starter moment than the three-phase induction motor.

- Settlingtime is less, which means that compared to th e threephase induction motor, its transiet duration is $r$ apidly dying-out,
- The six-phase induction motor draws a fairly low current at start time,

- The current of the six-phase induction motor is less than that of the three-phase induction motor in operating situations with a load of 5 and $10 \mathrm{Nm}$,

- Because the six-phase induction motor reaches a continuous state in less time, less copper loss occurs in the stator windings,

- Six-phase induction motors operate more efficiently because stator copper losses are less,

- Torque per ampere is increased, because its capacity for power handling is increased since the required po wer is split into several phases.

Multi-phase induction motors will be of great importance today, especially in electric / hybrid vehicle technology and space technology. Because in these areas, saving space (the area it occupies) and weight are among the priority issues.

With the same dimensions multi phase induction motors and three phase induction motors under the same conditions, compared to multi-phase induction motors produce more torque on them in a more advantageous position.

Some harmonics have been eliminated due to the placement of windings in the six-phase induction motor. Control of induction motors with inverters has become quite easy. In induction motor control with inverter, a much more efficient and reliable control can be realized by using modulation techniques. Especially with the space vector pulse width modulation technique, more efficient multi-phase induction motor control can be achieved by reducing harmonics.

\section{REFERENCES}

[1] Akman O. Ürkmez A.,2005, Asenkron Motor Tasarımının Bilgisayar Programı İle Gerçekleştirilmesi, Makina Tek Dergisi

[2] Ward, E.E., and Ha" rer, H.: 'Preliminary investigation of an invertor-fed 5-phase induction motor', Proc. IEE., 1969, 116, (6), pp. 980-984

[3] Y. Zhao, T.A. Lipo, "Space- vector PWM control of dual three phase induction machine using vector space decomposition", IEEE Trans. on Ind. Appin., Vol.31, No.5 Sept./Oct.1995,

[4] G.K. Singh, "Multiphase induction machine drive research - a survey", Electric Power system Research, Vol.61, 2002, pp.139-147.

[5] Sarıŏlu, M.K., Boğosyan, S. Ve Gökaşan, M. (2003), Asenkron Makinalar ve Kontrolü, Birsen Yayınevi, 392 s.

[6] K. Gopalkumar, Mahopatra, "A novel scheme for six phase induction motor with open end windings." 28th Annual Conference of IEEE Industrial Electronics Society, Spain. 5th - 8 th November, 2002.

[7] Emil Levi, "Recent Developments in High Performance VariableSpeed Multiphase Induction Motor Drives" Sixth International Symposium Nikola Tesla, Belgrade, Serbia. 18th - 20th October, 2006.

[8] Gülez K., 1999, Asenkron Motorların DSP (Sayısal İşaret İşleyici) Tabanlı Bir Kontrol Sistemi Kullanarak YSA (Yapay Sinir Ağları) ile Performansının Artırılması, Doktora Tezi, Yıldız Teknik Üniversitesi.

[9] Mandal Sumit,"Performance Analysis of Six-Phase Induction Motor" International Journal of Engineering Research \& Technology (IJERT),Vol.4,No.02 Feb.2015.

\section{BIOGRAPHIES}

Ismail Sarigul born in 1995 in Elazig-Turkey. He received B.sc degree from Firat University. He is a M. Sc student at Firat University. He is currently Research Assistant in the Electrical and Electronic Dept. of Inonu University. His research interest areas are electrical machines, drive systems and power electronics.

Mehmet Ozdemir born in 1958 in Elazig-Turkey. Received B.Sc., M.Sc. and $\mathrm{Ph} . \mathrm{D}$ degrees in Electrical Engineering from Firat University (Elazig-Turkey) in 1980, 1984 and 1993, respectively. He is currently Associate Professor in the Electrical and Electronic Dept. of Firat University. His area of interest is Electrical Machines and Drives. 